\title{
Front Matter: Volume 6436
}

, "Front Matter: Volume 6436," Proc. SPIE 6436, Complex Dynamics and Fluctuations in Biomedical Photonics IV, 643601 (12 March 2007); doi: 10.1117/12.727240

SPIE. Event: SPIE BiOS, 2007, San Jose, California, United States 


\section{PROGRESS IN BIOMEDICAL OPTICS AND IMAGING}

Vol. 8, No.13

\section{Complex Dynamics and \\ Fluctuations in \\ Biomedical Photonics IV}

Valery V. Tuchin

Editor

20 and 23 January 2007

San Jose, California, USA

Sponsored and Published by

SPIE-The International Society for Optical Engineering

Volume 6436

The International Society

for Optical Engineering

Proceedings of SPIE-The International Society for Optical Engineering, 9780819465498, v. 6436

SPIE is an international technical society dedicated to advancing engineering and scientific applications of optical, photonic, imaging, electronic, and optoelectronic technologies. 
The papers included in this volume were part of the technical conference cited on the cover and title page. Papers were selected and subject to review by the editors and conference program committee. Some conference presentations may not be available for publication. The papers published in these proceedings reflect the work and thoughts of the authors and are published herein as submitted. The publisher is not responsible for the validity of the information or for any outcomes resulting from reliance thereon.

Please use the following format to cite material from this book:

Author(s), "Title of Paper," in Complex Dynamics and Fluctuations in Biomedical Photonics IV, edited by Valery V. Tuchin, Proceedings of SPIE Vol. 6436 (SPIE, Bellingham, WA, 2007) Article CID Number.

ISSN 1605-7422

ISBN 9780819465498

Published by

SPIE-The International Society for Optical Engineering

P.O. Box 10, Bellingham, Washington 98227-0010 USA

Telephone 1 360/676-3290 (Pacific Time) · Fax 1 360/647-1445

http://www.spie.org

Copyright @ 2007, The Society of Photo-Optical Instrumentation Engineers

Copying of material in this book for internal or personal use, or for the internal or personal use of specific clients, beyond the fair use provisions granted by the U.S. Copyright Law is authorized by SPIE subject to payment of copying fees. The Transactional Reporting Service base fee for this volume is $\$ 18.00$ per article (or portion thereof), which should be paid directly to the Copyright Clearance Center (CCC), 222 Rosewood Drive, Danvers, MA 01923. Payment may also be made electronically through CCC Online at http://www.copyright.com. Other copying for republication, resale, advertising or promotion, or any form of systematic or multiple reproduction of any material in this book is prohibited except with permission in writing from the publisher. The CCC fee code is 1605$7422 / 07 / \$ 18.00$.

Printed in the United States of America. 


\section{Contents}

vii Conference Committee

ix Introduction

SESSION 1 COHERENT-DOMAIN METHODS FOR MONITORING OF TISSUE COMPLEX STRUCTURE

643602 Studies of dynamic processes in biomedicine by high-speed spectral optical coherence tomography (Invited Paper) [6436-01]

M. Wojtkowski, A. Kowalczyk, Nicolaus Copernicus Univ. (Poland)

643605 Penetration depth of low-coherence enhanced backscattering photons in the sub-diffusion regime [6436-04]

H. Subramanian, P. Pradhan, Y. L. Kim, V. Backman, Northwestern Univ. (USA)

\section{SESSION 2 BIOPHOTONIC IMAGING, SPECTROSCOPY, AND MICROSCOPY}

643606 Analyzing cell structure and dynamics with confocal light scattering and absorption spectroscopic microscopy (Invited Paper) [6436-05]

L. Qiu, E. Vitkin, H. Fang, M. M. Zaman, C. Andersson, S. Salahuddin, M. D. Modell, S. D. Freedman, E. B. Hanlon, I. Itzkan, L. T. Perelman, Beth Israel Deaconess Medical Ctr., Harvard Univ. (USA)

643608 The characterization of a phase contrast $x$-ray imaging prototype [6436-07] M. Donovan, D. Zhang, Univ. of Oklahoma (USA); W. R. Chen, Univ. of Central Oklahoma (USA); H. Liu, Univ. of Oklahoma (USA)

64360A Evaluation the development of focal cerebral ischemia in rats by optical imaging based on the spreading depression signals [6436-22]

S. Chen, Z. Feng, S. Zeng, Q. Luo, P. Li, Britton Chance Ctr. For Biomedical Photonics, Huazhong Univ. of Science and Technology (China)

Pagination: Proceedings of SPIE follow an e-First publication model, with papers published first online and then in print and on CD-ROM. Papers are published as they are submitted and meet publication criteria. A unique, consistent, permanent citation identifier (CID) number is assigned to each article at the time of the first publication. Utilization of CIDs allows articles to be fully citable as soon they are published online, and connects the same identifier to all online, print, and electronic versions of the publication.

SPIE uses a six-digit CID article numbering system in which:

- The first four digits correspond to the SPIE volume number.

- The last two digits indicate publication order within the volume using a Base 36 numbering system employing both numerals and letters. These two-number sets start with 00, 01, 02, 03, 04, 05, 06, 07, 08, 09, 0A, OB ... 0Z, followed by 10-1Z, 20-2Z, etc.

The CID number appears on each page of the manuscript. The complete citation is used on the first page, and an abbreviated version on subsequent pages. 
64360B Effect of erythrocyte aggregation on optical transmission of blood (Invited Paper) [6436-09]

L. D. Shvartsman, The Hebrew Univ. of Jerusalem (Israel); I. Fine, Elfi-Tech Ltd. (Israel)

64360C In vivo dynamic light scattering measurements of red blood cell aggregation [6436-10]

I. Fine, A. Kaminsky, Elfi-Tech Ltd. (Israel)

64360D Advances in intravital microscopy for monitoring cell flow dynamics in vivo (Invited Paper) [6436-11]

V. Kalchenko, A. Harmelin, Weizmann Institute of Science (Israel); I. Fine, Elfi Tech Ltd. (Israel); V. Zharov, Arkansas Cancer Research Ctr., Univ. of Arkansas for Medical Sciences (USA); E. Galanzha, Arkansas Cancer Research Ctr., Univ. of Arkansas for Medical Sciences (USA) and Saratov State Univ. (Russia); V. Tuchin, Saratov State Univ. (Russia)

SESSION 4 ADAPTIVE SYSTEMS AND NONLINEAR DYNAMIC PROCESSES

64360G Mitochondrial dysfunction modulates nonlinear dynamics in liver cell metabolism [6436-14] V. K. Ramanujan, B. A. Herman, The Univ. of Texas Health Science Ctr. at San Antonio (USA)

SESSION 5 DYNAMICS OF LASER-INDUCED NANOPARTICLE PHOTOTHERMOLYSIS

64360 Laser-induced thermal explosion mode for selective nano-photothermolysis of cancer cells (Invited Paper) [6436-16]

R. R. Letfullin, Rose-Hulman Institute of Technology (USA); V. P. Zharov, Arkansas Cancer Research Ctr., Univ. of Arkansas for Medical Sciences (USA); C. Joenathan, Rose-Hulman Institute of Technology (USA); T. F. George, Univ. of Missouri, St. Louis (USA)

64360 J Analyzing chaos in the pressure generated by laser absorption by microparticles [6436-17] E. Faraggi, B. S. Gerstman, Florida International Univ. (USA)

\section{POSTER SESSION}

64360K Mining and learning latent dynamics in biological manifolds [6436-18]

E. Capobianco, CRS4 Bioinformatics Lab. (Italy)

64360L Variations of piece-wise liner ID one-parameter chaotic map [6436-19]

V. M. Anikin, A. S. Remizov, S. S. Arkadaksky, Saratov State Univ. (Russia)

643600 Influence of refractive index and molecular weight of alcohol agents on skin optical clearing effect [6436-24]

Z. Mao, Wuhan Institute of Physical Education (China) and Britton Chance Ctr. For Biomedical Photonics, Huazhong Univ. of Science and Technology (China); Y. Zheng, Y. Hu, W. Lu, Q. Luo, D. Zhu, Britton Chance Ctr. For Biomedical Photonics, Huazhong Univ. of Science and Technology (China)

64360P Richardson-Lucy deconvolution for two-photon fluorescence images via non-linear diffusion equation pre-filtering [6436-25]

H. Zhang, Z. Zhang, Q. Luo, S. Zeng, Huazhong Univ. of Science and Technology (China) 
64360Q Chicken embryo outflow tract flow measurement using 840-nm and 1300-nm ultra-high speed spectral optical coherence tomography [6436-26]

Z. Ma, R. K. Wang, Oregon Health and Science Univ. (USA) and Tianjin Univ. (China)

64360R Tactile information processing in the trigeminal complex of the rat [6436-27]

A. N. Pavlov, A. N. Tupitsyn, Saratov State Univ. (Russia); V. A. Makarov, F. Panetsos, A. Moreno, V. Garcia-Gonzalez, A. Sanchez-Jimenez, Univ. Complutense de Madrid (Spain)

64360S Near-infrared absorbance measurements of hemoglobin solutions incubated with glucose [6436-28]

O. S. Zhernovaya, V. V. Tuchin, Saratov State Univ. (Russia); I. Meglinski, L. Ritchie, Cranfield Univ. (United Kingdom)

$64360 U$ Dynamics of morphofunctional erythrocyte properties during intravenous glucose injection in patients with coronary heart disease [6436-30]

L. I. Malinova, Saratov Scientific Research Institute of Cardiology (Russia) and Saratov State Medical Univ. (Russia); G. V. Simonenko, Saratov State Univ. (Russia); T. P. Denisova, Saratov State Medical Univ. (Russia); V. V. Tuchin, Saratov State Univ. (Russia)

64360V Cell-cell interaction in blood flow in patients with coronary heart disease (in vitro study) [6436-31]

L. I. Malinova, Saratov Scientific Research Institute of Cardiology (Russia) and Saratov State Medical Univ. (Russia); G. V. Simonenko, Saratov State Univ. (Russia); T. P. Denisova, Saratov State Medical Univ. (Russia); V. V. Tuchin, Saratov State Univ. (Russia)

64360W Noise-induced firing patterns in generalized neuron model with subthreshold oscillations [6436-32]

L. Ryazanova, Y. Trenikhina, R. Zhirin, D. Postnov, Saratov State Univ. (Russia)

64360X Application of spectral method for monitoring of hemoglobin glycation [6436-33]

E. N. Lazareva, V. V. Tuchin, Saratov State Univ. (Russia)

64360Y Tapered single mode fiber tip for high lateral resolution imaging in optical coherence tomography [6436-34]

Y. Verma, K. D. Rao, S. K. Mohanty, P. K. Gupta, Raja Ramanna Ctr. for Advanced Technology (India)

643602 Monte Carlo study of skin optical clearing to enhance light penetration in the tissue [6436-35]

A. N. Bashkatov, V. V. Tuchin, E. A. Genina, M. M. Stolnitz, D. M. Zhestkov, Saratov State

Univ. (Russia); G. B. Altshuler, I. V. Yaroslavsky, Palomar Medical Technologies, Inc. (USA)

643611 Optical properties reconstruction of layered tissue and experimental demonstration [6436-37]

T. Guan, H. Zhao, Z. Wang, D. Yu, Tianjin Univ. (China)

Author Index 
Downloaded From: https://www.spiedigitallibrary.org/conference-proceedings-of-spie on 26 Apr 2023

Terms of Use: https://www.spiedigitallibrary.org/terms-of-use 


\section{Conference Committee}

Symposium Chairs

James G. Fujimoto, Massachusetts Institute of Technology (USA)

R. Rox Anderson, Wellman Center for Photomedicine, Massachusetts

General Hospital, and Harvard School of Medicine (USA)

Program Track Chairs

Tuan Vo-Dinh, Duke University (USA)

Anita Mahadevan-Jansen, Vanderbilt University (USA)

Conference Chair

Valery V. Tuchin, Saratov State University (Russia)

Program Committee

Vadim S. Anischenko, Saratov State University (Russia)

Wei R. Chen, University of Central Oklahoma (USA)

Bernard Choi, University of California/Irvine (USA)

Omar S. Khalil, Abbott Laboratory (USA)

Sean J. Kirkpatrick, Oregon Health and Science University (USA)

Jürgen Lademann, Charité-Universität Medizin Berlin (Germany)

Hong Liu, University of Oklahoma (USA)

Qingming Luo, Huazhong University of Science and Technology (China)

Alexander V. Priezzhev, M.V. Lomonosov Moscow State University (Russia)

Vladislav Y. Toronov, University of Illinois at Urbana-Champaign (USA)

Ruikang K. Wang, Oregon Health and Science University (USA) and Tianjin University (China)

Vladimir P. Zharov, University of Arkansas for Medical Sciences (USA)

Dmitry A. Zimnyakov, Saratov State University (Russia)

\section{Session Chairs}

1 Coherent-Domain Methods for Monitoring of Tissue Complex Structure Sean J. Kirkpatrick, Oregon Health and Science University (USA)

2 Biophotonic Imaging, Spectroscopy, and Microscopy

Sean J. Kirkpatrick, Oregon Health and Science University (USA)

3 Blood and Lymph Flow Complex Dynamics

Sean J. Kirkpatrick, Oregon Health and Science University (USA)

$4 \quad$ Adaptive Systems and Nonlinear Dynamic Processes

Vladislav Y. Toronov, University of Illinois at Urbana-Champaign (USA)

5 Dynamics of Laser-Induced Nanoparticle Photothermolysis

Sean J. Kirkpatrick, Oregon Health and Science University (USA) 


\section{Poster Session}

Valery V. Tuchin, Saratov State University (Russia) 


\section{Introduction}

These proceedings are from the conference on Complex Dynamics and Fluctuations in Biomedical Photonics IV, held January 20, 2007, during the SPIE Photonics West symposium in San Jose, California. It was a two-day meeting featuring 36 oral and poster presentations from leading international research groups.

The goal of the conference was to gather essentially different groups of leading researchers and students - such as biophysicists, physicians, mathematicians, optical and laser engineers - to facilitate future progress in the development of optical and laser technologies based on complex dynamics and fluctuations approaches towards biomedical science and clinical applications. These approaches should be useful for diagnosis and therapy of dangerous diseases such as those of the heart and vascular systems, and cancer, psoriasis, mental illness, and many other conditions that manifest as a breach of the living organism's auto-control systems at the level of molecule, cell, organ, or organism as a whole. We hope that the proceedings of this conference will contribute to the development of such interdisciplinary fields of science and applications as complex dynamics and structures of living systems, biomedical optics, and laser medicine, and that it will be helpful for scientists, medical doctors, engineers, and students.

The conference was organized into several sessions: Coherent-Domain Methods for Monitoring of Tissue Complex Structure; Biophotonic Imaging, Spectroscopy, and Microscopy; Blood and Lymph Flow Complex Dynamics; Adaptive Systems and Nonlinear Dynamic Processes; and Dynamics of Laser-Induced Nanoparticle Photothermolysis; with six invited papers.

During the oral session on Coherent-Domain Methods for Monitoring of Tissue Complex Structure and the poster session, studies of dynamical processes in biomedicine using high-speed spectral OCT, including early development of chick embryonic heart imaging at $766 \mathrm{~nm}$ in vivo with high-fidelity, were presented and discussed. Results of basic research on the information capacity of coherence-gated imaging through turbid media and penetration depth of low-coherence enhanced backscattering photons in the subdiffusion regime were also analyzed. Tapered single-mode fiber tip for high lateral resolution imaging in OCT was described. Two papers on speckle technologies, such as speckle tracking-based elastography for skin monitoring and a signal-to-noise analysis for laser speckle contrast imaging, were presented.

In the session on Biophotonic Imaging, Spectroscopy, and Microscopy, cell structure and dynamics using confocal light scattering and absorption 
spectroscopic microscopy, new Monte Carlo-based diffuse optical imaging technique, the computed radiography $x$-ray phase contrast imaging system, the influence of nutrition and stress factors on the antioxidative potential of the skin, two-photon microscopy image slices restoration using modified nonlinear anisotropic diffusion filter, and spectral changes in skin autofluorescence under application of different clearing agents were analyzed and discussed.

The Blood and Lymph Flow Complex Dynamics session included a few papers on complex effects of erythrocyte aggregation on optical transmission of blood, on in vivo measurement of blood aggregation by using DLS, and on advanced in vivo microscopy for monitoring of cell flow dynamics, on in vivo integrated lymph and blood flow cytometry for real-time monitoring of cell blood-lymph traffic, and cell-cell interaction in blood flow in patients with coronary heart disease (in vitro study).

In the session on Adaptive Systems and Nonlinear Dynamic Processes and the corresponding portion of the poster session, the following topics were discussed: current adaptive optic ophthalmologic techniques and new methods of increasing field-of-view of fundus cameras, nonlinear dynamics in liver cell metabolism modulated by mitochondrial dysfunction, near-infrared fluorescence dynamic optical imaging of lymphatic vasculature, noise-induced firing patterns in generalized neuron model with subthreshold oscillations, tactile information processing in the trigeminal complex of the rat, and variations of piece-wise liner ID map modeling neuron activity.

During the session on Dynamics of Laser-Induced Nanoparticle Photothermolysis two main topics were discussed: laser-induced thermal explosion mode for selective nano-photothermolysis of cancer cells and chaos in the pressure generated by laser absorption by microparticles.

In addition to these topics, the following problems also were discussed in the poster session: mining and learning latent dynamics in biological manifolds, light scattering application for bacterial cell monitoring during cultivation process, changes in efficiency of optical clearing of mouse skin in vivo and in vitro induced by different alcohol agents, Monte Carlo study of skin optical clearing to enhance light penetration in the tissue, near-infrared absorbance measurements of hemoglobin solutions incubated with glucose, and monitoring of hemoglobin glycation using spectral and refraction measurements.

The conference chair would like to thank the members of the technical program committee for their help in organizing the conference. I sincerely appreciate the support of SPIE and its staff. Finally, I would like to thank all of the conference attendees and manuscript authors for their contributions and participation, especially invited speakers, which helped to make this meeting a success. 